\title{
Purification and Partial Characterization of an Extracellular Melanoprotein from the Fungus Venturia inaequalis
}

\author{
Prikhshayat Singh ${ }^{\mathrm{a}}$, Markus Piotrowski ${ }^{\mathrm{b}}$, and Achim E. Gau ${ }^{\mathrm{c}, *}$ \\ a Indian Agricultural Research Institute, Biochemistry Division, New Delhi 110012, India \\ b Lehrstuhl für Pflanzenphysiologie, Ruhr-Universität Bochum, D-44780 Bochum, Germany \\ c Institut für Botanik, Universität Hannover, D-30419 Hannover, Germany. \\ Fax: (49) 511-7623992. E-mail: achim.gau@botanik.uni-hannover.de \\ * Author for correspondence and reprint requests \\ Z. Naturforsch. 60 c, 109-115 (2005); received August 24/September 20, 2004
}

The fungus Venturia inaequalis clone No. 36 isolated from Malus domestica cv. Gloster excretes a melanoprotein of $36 \mathrm{kDa}$ in relatively high amounts during growth in liquid culture. The protein was isolated from the culture medium and purified to homogeneity. It was shown to contain melanin. After raising an antiserum against the isolated protein, the protein could be shown to be located in the apoplast fluid of the $V$. inaequalis infected Malus domestica $\mathrm{cv}$. Elstar. Partial sequencing of the protein revealed no significant sequence homologies to so far sequenced proteins. The melanoprotein binds ferrous and ferric iron. Moreover, it could be shown that the binding of ferric iron (but not of ferrous iron) leads to a change in the absorbance of the protein suggesting a modification of the protein by ferric, but not by ferrous, iron. In addition to iron, the protein also binds copper, but does not bind manganese or nickel. A possible function of this protein in the recruiting and transport of iron and copper and/or in the protection of the fungus by metal-ion mediated oxidative stress is discussed.

Key words: Apoplast, Melanoprotein, Venturia inaequalis

\section{Introduction}

The facultative biotrophically growing fungus Venturia inaequalis damages apple trees, such as Malus domestica cv. Gloster, by causing apple scab. During the infection, the fungus penetrates the cuticle of the host plant and forms a subcuticular mycelium in the apoplast, which eventually leads to new conidia. For prevention or at least reduction of the fungal infection the plant starts its defense machinery which includes an oxidative burst and the synthesis of a number of pathogenesis-related proteins (PR proteins) (Gau et al., 2004). When no successful restriction of the fungus growth could be achieved, the formation of necrotic tissues is initiated to avoid the spreading of the fungus on the plant. To achieve a successful life cycle of the fungus on the plant, a number of protecting reactions are initiated by the fungus.

Although the life cycle of $V$. inaequalis on $M$. domestica is well characterized (MacHardy, 1996),

Abbreviations: ESI Q-ToF, electron spray ionisation quadrupole time of flight; HEPES, 4-(2-hydroxyethyl)piperazine ethanesulfonic acid; IWF, intercellular washing fluid. there is little information available which proteins are excreted by the fungus during infection. Initial work on this aspect provided evidence that $V$. inaequalis (Cke) Wint. excretes a dark-brown protein which was shown to contain melanin (Hignett and Kirkham, 1967; Hignett, 1973; Hignett et al., 1984). This protein causes an increase in the number of lesions on the inoculated plants. Moreover, iron was shown to bind tightly to the protein. When iron salts were applied with the inoculum, the numbers of lesions were greatly reduced. These and additional results were discussed in relation to changes in membrane permeability which occur during infection (Hignett and Kirkham, 1967).

In this paper we present the isolation, a partial characterization, and the localization in the host plant of the melanoprotein isolated from $V$. inaequalis clone No. 36 from Malus domestica cv. Gloster.

\section{Materials and Methods}

Cultivation of $V$. inaequalis and preparation of extracellular melanoprotein

A clone of Venturia inaequalis, isolated from a leaf of Malus domestica (cv. Gloster) in Ruthe 
(Sarstedt, Germany) and designated as cultivar No. 36, was cultivated on PDA (potato-dextrose agar) (Parker et al., 1995). For the preparation of the extracelluar melanoprotein a $100 \mathrm{ml}$ Erlenmeyer-flask containing $50 \mathrm{ml}$ PD broth was inoculated with a PDA piece of $1 \mathrm{~cm}$ diameter containing mycelium of $V$. inaequalis. The liquid culture was incubated at $19{ }^{\circ} \mathrm{C}$ for three weeks under gentle shaking. Afterwards, the liquid culture was harvested and centrifuged for $30 \mathrm{~min}$ at $10,000 \times g$. The supernatant was dialysed several times against $10 \mathrm{~mm}$ K-phosphate buffer, $\mathrm{pH} 7.0$, at $4{ }^{\circ} \mathrm{C}$ and subsequently concentrated by means of a Vivaspin concentrator (cut off 5000 Dalton; Vivascience, Hannover, Germany).

\section{Purification of the melanoprotein by DEAE column chromatography}

The concentrated melanoprotein was dialysed overnight in the presence of $20 \mathrm{~mm}$ Na-acetate $\mathrm{pH} 4.8$, containing $0.05 \%$ Tween 20 . After a centrifugation step at $10,000 \times g$ for $15 \mathrm{~min}$, the supernatant was loaded onto a DEAE Sepharose column (size $2 \times 10 \mathrm{~cm}$ ) equilibrated with the above indicated buffer. After washing the column with equilibration buffer the melanoprotein was eluted using a linear salt gradient from 0 to $500 \mathrm{~mm} \mathrm{NaCl}$.

\section{Gel electrophoresis, silver staining, antisera production and immunoblotting}

SDS-PAGE and sample denaturation were carried out as described by Schägger and von Jagow (1987). Silver staining was done according to Blum et al. (1987). A polyclonal antiserum against the melanoprotein was raised in goat. Melanoprotein $(500 \mu \mathrm{g})$ was dialyzed against $10 \mathrm{~mm}$ sodium phosphate buffer (pH 7.0) containing $0.05 \%$ SDS. After dilution with an equal volume of Freund's complete adjuvance, the emulsion was divided into two equal parts and injected subcutaneously into a goat and after 3 weeks into the hingleg muscles. The bleeding was 3 weeks after the second immunization. Immunoblotting was performed by using $0.45 \mu \mathrm{m}$ pore size nitrocelluose filters (Towbin et al., 1979). Blots were blocked with 5\% skim milk and incubated with antibodies against melanoproteins (goat, dilution 1:500 in milk), the latter were detected by anti-goat-IgG from rabbit goat labelled with alkaline phosphatase (dilution 1:20,000; Sigma, Munich, Germany).

\section{Protein digestion and sequencing}

Proteins were excised after Coomassie brilliant blue staining from SDS-PAGE gels and digested according to Jensen et al. (1998). Peptide fragments were extracted from the gels by washing several times with the same volume of extraction solution $(50 \mu \mathrm{l}$ of a $1: 1$ mixture of $5 \%$ formic acid and acetonitrile). The extracted solutions were combined and concentrated with ZipTips C18 (Millipore). De novo sequencing was done on a quadrupole/time-of-flight hybrid mass spectrometer (Q-TOF2 Micromass, Waters, Manchester, United Kingdom) in positive-ion mode. Amino acid sequences were identified by homology search using the program PeptideSearch (EMBL, Heidelberg, Germany).

\section{Isolation of thylakoid membranes and measurement of PSII activity}

Thylakoid membranes from pea were isolated according to the method described by Berthold et al. (1981). PSII activities were determined by $\mathrm{O}_{2}$ exchange using a Clark type electrode (Specht et al., 1987). The reaction mixture of $2.5 \mathrm{ml}$ contained: $50 \mathrm{~mm} \mathrm{NaOH}, \mathrm{pH} 6.5,1 \mathrm{~mm}$ phenyl- $p$ benzoquinone and $25 \mu \mathrm{g} \mathrm{Chl}$.

\section{Size exclusion chromatography}

Size exclusion chromatography was performed on a Superose 12 column equilibrated with $10 \mathrm{~mm}$ K-phosphate buffer, pH 7.0 (Amersham Biosciences, Freiburg, Germany), and calibrated with catalase $(240 \mathrm{kDa})$, bovine serum albumin (68 kDa), ovalbumin (45 kDa), carbonic anhydrase $(30 \mathrm{kDa})$ and cytochrome $\mathrm{C}(12 \mathrm{kDa})$. The liquid flow rate was adjusted to $0.5 \mathrm{ml} / \mathrm{min}$.

\section{Isolation of intercellular washing fluid}

All leaves of the inoculated plants were selected for the isolation of apoplastic fluid. This was performed according to Gau et al. (2004). The leaves were cut off from the petiole, infiltrated for $5 \mathrm{~min}$ with PBS buffer under vacuum and fixed between two transparent strips. The leaves were oriented to the cut area to the bottom of the centrifuge tube and centrifuged for $5 \mathrm{~min}$ at $50 \times g$ in a Jouan AC50.10 rotor to remove the excess of liquid. The apoplastic fluid was collected by an additional centrifugation step for $15 \mathrm{~min}$ at $700 \times g$ and finally stored at $-20^{\circ} \mathrm{C}$. Controls were carried out to as- 
certain that no leakage of proteins occurred during the centrifugation step as described in the literature (Anderson et al., 1994).

\section{UV/Vis spectroscopy}

Absorbance spectra were measured with a Beckman DU7500 absorbance spectra photometer.

\section{Iron determination}

Protein samples as well as control samples $(250 \mu \mathrm{l})$ were treated by addition of $1 \mathrm{mM} \mathrm{Fe}^{2+}$, $\mathrm{Fe}^{3+}, \mathrm{Cu}^{2+}, \mathrm{Ni}^{2+}$ or $\mathrm{Mn}^{2+}$ solution to a final concentration of $160 \mu \mathrm{M}$. Subsequently, the samples were dialyzed extensively 3 times against $500 \mathrm{ml}$ water or metal chelator (10 mм Na-EDTA, pH 7.0, for $\mathrm{Cu}^{2+}, \mathrm{Mn}^{2+}, \mathrm{Ni}^{2+}$ or $1 \mathrm{~mm} o$-phenanthroline, $\mathrm{pH} 7.0$, for $\mathrm{Fe}^{3+}$ or $\mathrm{Fe}^{2+}$ ) and finally mixed with $500 \mu \mathrm{l} 65 \% \mathrm{HNO}_{3}$ and boiled for $1 \mathrm{~h}$. Afterwards the samples were filled up to $2 \mathrm{ml}$ and after a centrifugation step at $10,000 \times g$ for $10 \mathrm{~min}$, the samples were measured in an inductively coupled plasma at the following wavelengths: $324.8 \mathrm{~nm}$ $(\mathrm{Cu}), 259.9 \mathrm{~nm}(\mathrm{Fe}), 352.4 \mathrm{~nm}(\mathrm{Ni})$ and $257.6 \mathrm{~nm}$ (Mn) with an inductive coupled plasma atomic absorbance spectrometer (Spectroflame-EOP, Spectro Analytical Instruments, Kleve, Germany).

\section{Results and Discussion}

Purification, determination of the molecular mass and partial amino acid sequencing of the melanoprotein from $V$. inaequalis clone No. 36 isolated from M. domestica cv. Gloster

Preliminary investigations on the interaction of $M$. domestica with the fungus $V$. inaequalis and a comparison of several $V$. inaequalis isolates provided evidence that the clone No. 36 isolated from M. domestica cv. Gloster (subsequently called $V$. inaequalis) excreted rather high amounts of a dark-brown protein into liquid culture, the excreted amount being significantly higher than that e.g. excreted by $V$. inaequalis clone No. 15 isolated from $M$. domestica $\mathrm{cv}$. Elstar.

\section{Protein purification}

The culture medium used for growth of $V$. inaequalis was employed as starting material for the purification of this dark-brown protein. After growth of the fungus for three weeks, the culture was centrifuged and the supernatant containing the dark-brown protein was dialyzed and then concentrated by a Vivaspin concentrator (cut off 5000 Dalton). After concentration, the protein fraction was again dialyzed and then submitted to chromatography on a DEAE Sepharose column (see details under Materials and Methods). At neutral or slightly alkaline $\mathrm{pH}$ the protein bound extremely tightly to the DEAE Sepharose column and could not be eluted. For this reason the chromatography was performed at $\mathrm{pH} 4.8$ implying that the protein is a highly acidic one. This chromatography resulted in a homogenous protein of the molecular mass $36 \mathrm{kDa}$ on the basis of SDSPAGE (see Fig. 1B). The molecular mass of the major fraction (peak No. 2, Fig. 1A) of the native protein determined by size exclusion chromatography was of approximately $30 \mathrm{kDa}(26-40 \mathrm{kDa})$ indicating that the major amount of the protein consisted of monomers. Besides the monomers, a small fraction (approximately 10\%; peak No. 1 of Fig. 1A) existed as an oligomer with a molecular mass being larger than the exclusion size of the Superose 12 column (>2000 kDa).

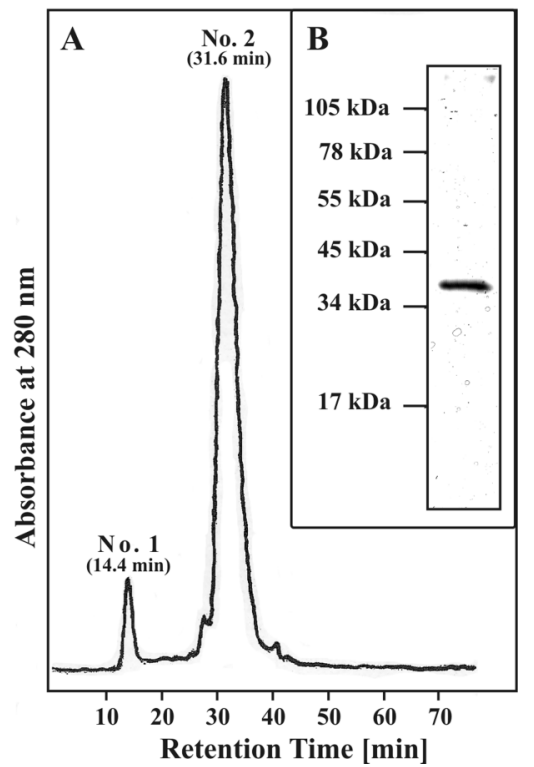

Fig. 1. A: Elution profile of the purified melanoprotein after chromatography on a Superose 12 column. Peak No. 1 represents the high molecular mass complex of the melanoprotein $(>2000 \mathrm{kDa})$ and peak No. 2 the monomer of the protein of $36 \mathrm{kDa}$. The molecular mass standards were catalase $(240 \mathrm{kDa})$, bovine serum albumin (68 kDa), ovalbumin $(45 \mathrm{kDa})$, carbonic anhydrase $(30$ $\mathrm{kDa})$, and cytochrome C (12 kDa). B: SDS-PAGE of the purified melanoprotein ( $9 \%$ acrylamide gel). The lane was loaded with $10 \mu \mathrm{g}$ protein. 


\section{Protein digestion and sequencing}

For obtaining partial amino acid sequences, the isolated protein was digested with trypsin and the polypeptide fragments were identified by ESI Q-ToF mass spectrometry. This resulted in 11 tryptic peptide fragments with a contiguous amino acid sequence from 6 to 23 amino acids, corresponding to $14,610 \mathrm{Da}$ which represents about $40 \%$ of the protein. The derived amino acid sequences are listed in Table I. Homology search in different databases (NCBI, Swiss Prot, EMBL) only resulted in weak similarities to known proteins, expressed sequence tags or unknown ORFs in sequenced genomes. The peptides No. 1 and No. 4 have some similarity to a hypothetical protein of Aspergillus nidulans that shows in part homology to $\beta$-1,3-glucosidase from Fusarium sporotrichioides which might be an indication that the protein has a hydrolytic activity, although this is not supported by the other obtained sequences.

\section{UV/Vis spectroscopy}

The logarithmic absorbance spectrum of the isolated protein shows an increase in the region from 350 to $500 \mathrm{~nm}$. The calculation of the logarithmic absorbance slope of -0.0038 indicates the presence of melanin in the purified dark-brown protein, since the logarithmic absorbance slope of the synthetic melanin obtained after oxidation by persulfate as well as the isolated melanin extracted by alkaline treatment followed by acid precipitation from the intact $V$. inaequalis strain 3B3-1 (El Bassam et al., 2002) have a value of -0.0040 . This result implies that the dark-brown chromophore of the protein isolated from $V$. inaequalis clone No. 36 isolated from $M$. domestica cv. Gloster also contains melanin and thus represents a melanoprotein.

\section{Interaction of the melanoprotein with metal ions}

Previous work has provided evidence that the melanoprotein from $V$. inaequalis isolate $\mathrm{E}_{1}$ interacts with ferrous sulfate and also with ferric citrate, while neither calcium nor magnesium ions were retained by the melanoprotein after prolonged dialysis. Our investigations confirm the binding of ferrous and ferric ions to the melanoprotein, and also confirm that iron in part is tightly bound, since a small fraction of iron remains bound to the protein, even after dialysis against the chelator $o$-phenanthroline or EDTA. In addi-

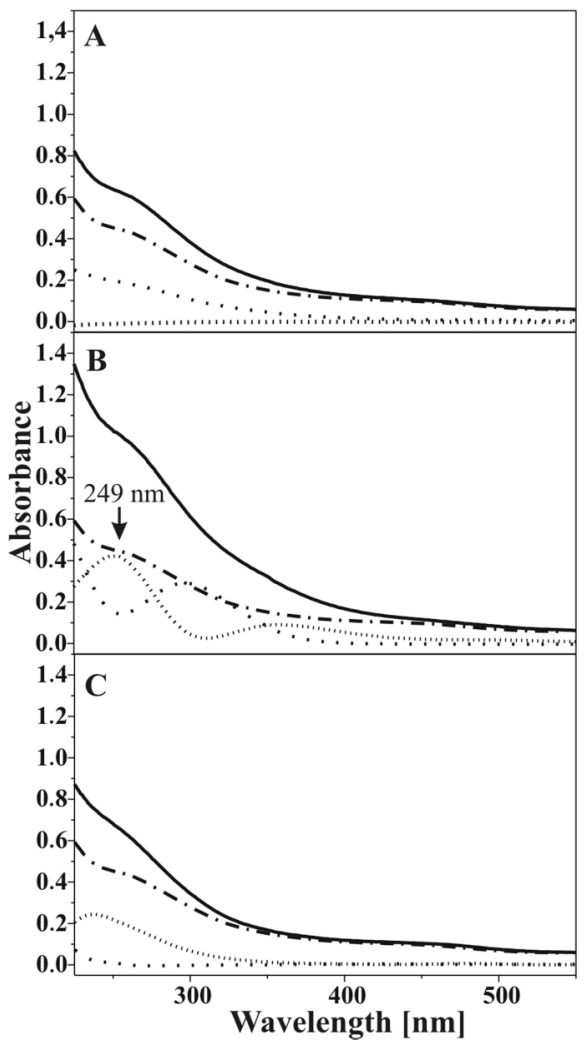

Fig. 2. Influence of selected metal salts on the isolated melanoprotein from $V$. inaequalis $(50 \mu \mathrm{g} / \mathrm{ml})$. Curves represent the absorbance of $(-\cdots, \cdot)$ melanoprotein from $V$. inaequalis without addition, $(-)$ melanoprotein after addition of metal salt, $(\cdots)$ metal salt, $(\cdots)$ melanoprotein after addition of metal salt and subtraction of the absorbance spectra of melanoprotein and metal salt. A: Effect of $160 \mu \mathrm{M} \mathrm{FeSO}$; B: effect of $160 \mu \mathrm{M} \mathrm{FeCl}$; C: effect of $160 \mu \mathrm{M} \mathrm{CuCl} 2$.

tion to iron, the protein binds also $\mathrm{Cu}$ (II) but does not bind $\mathrm{Mn}$ (II) and Ni(II) (see Table II). Moreover, it could be shown that $\mathrm{Fe}$ (III) and $\mathrm{Cu}$ (II) but not $\mathrm{Fe}$ (II) ions cause an absorbance change in the protein (see Fig. 2A, B, and C) suggesting that either $\mathrm{Fe}(\mathrm{III})$ and $\mathrm{Cu}(\mathrm{II})$ cause an oxidation of the chromophore or $\mathrm{Fe}(\mathrm{III})$ and $\mathrm{Cu}(\mathrm{II})$ cause a conformational change in the protein leading to a change in the absorbance of melanin.

The tight binding of $\mathrm{Fe}(\mathrm{II})$ to the protein can also be demonstrated by measuring the photosynthetic $\mathrm{O}_{2}$ evolution with isolated thylakoid membranes from peas (see Table III). Fe(II) ions cause an about $50 \%$ inhibition of the $\mathrm{O}_{2}$ evolution. When $\mathrm{Fe}(\mathrm{II})$ is preincubated with the melanopro- 


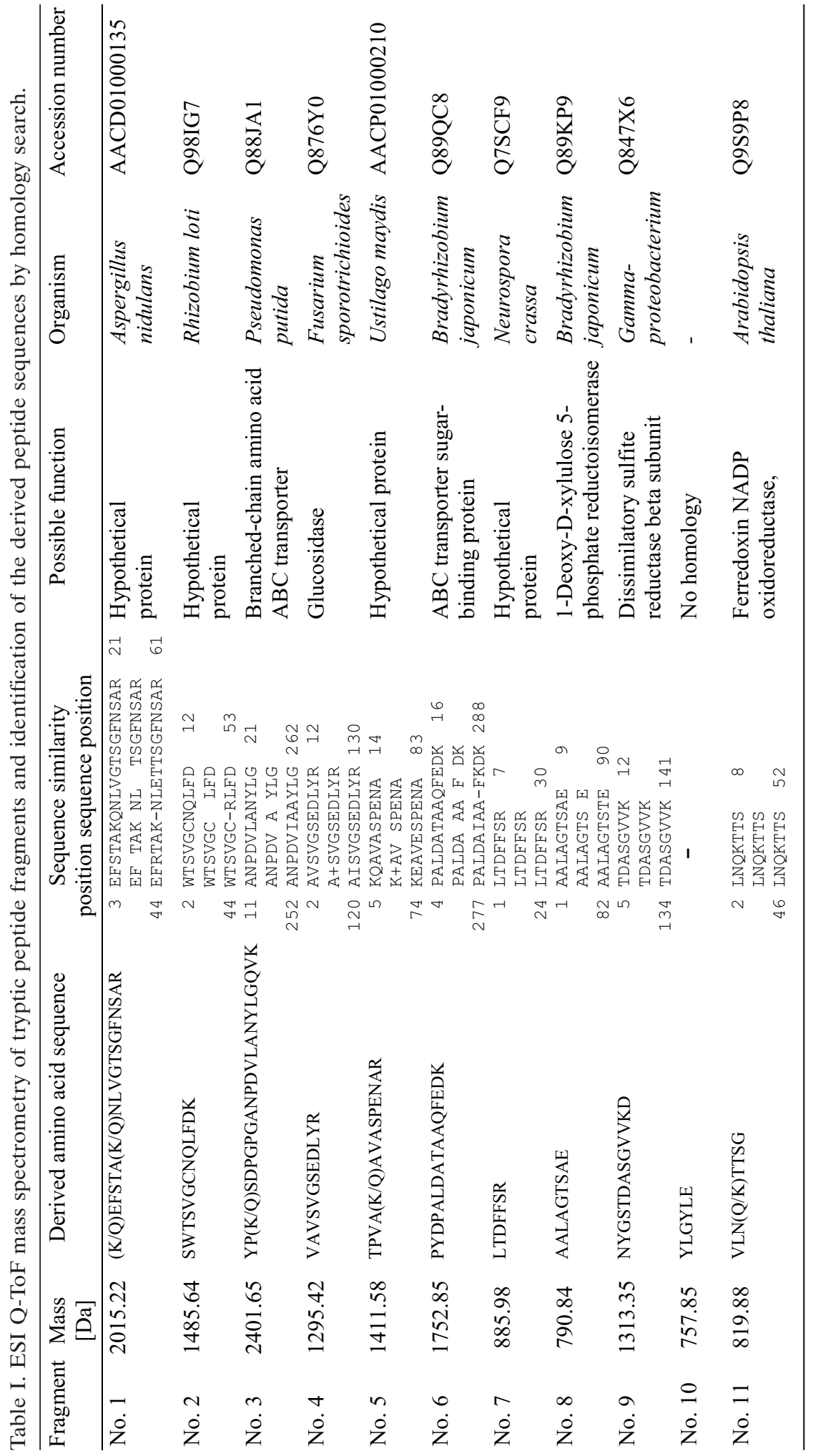


Table II. Determination of the metal binding capacity of the purified melanoprotein from $V$. inaequalis.

\begin{tabular}{lcc}
\hline $\begin{array}{l}\text { Treatment of } \\
\text { protein }\end{array}$ & $\begin{array}{c}\text { Dialysis } \\
\text { against } \mathrm{H}_{2} \mathrm{O} \\
\text { [g atom/mol protein] }\end{array}$ & $\begin{array}{c}\text { Dialysis } \\
\text { against chelator } \\
\text { [g atom/mol protein] }\end{array}$ \\
\hline $\begin{array}{l}\text { No preincubation } \\
\text { Preincubation with }\end{array}$ & 0 & 0 \\
$\begin{array}{l}160 \mu \mathrm{M} \mathrm{FeSO} \\
\text { Preincubation with }\end{array}$ & 1.3 & 0.3 \\
$160 \mu \mathrm{M} \mathrm{FeCl}_{3}$ \\
$\begin{array}{l}\text { Preincubation with } \\
160 \mu \mathrm{M} \mathrm{CuCl}_{2}\end{array}$
\end{tabular}

For this experiment the isolated melanoprotein $(1.60 \mathrm{mg} /$ $\mathrm{ml})$ was preincubated with metal salts as indicated for $30 \mathrm{~min}$ and then dialysed against bidest. $\mathrm{H}_{2} \mathrm{O}, 10 \mathrm{~mm}$ Na-EDTA, pH 7.0, or $1 \mathrm{~mm} o$-phenanthroline, $\mathrm{pH} 7.0$, for $48 \mathrm{~h}$ (with three changes of the dialysis solution). After the same treatment of the protein with $\mathrm{NiCl}_{2}$ or $\mathrm{MnCl}_{2}$ neither Ni nor Mn remained bound to the protein. The isolated protein before preincubation with metal contained neither iron nor copper or any other metal. The calculations of the metal:protein ratios were performed on the basis of the Lowry protein determination.

Table III. Measurement of photosynthetic oxygen evolution of isolated thylakoid membranes from pea leaves in the presence of phenyl-p-benzoquinone as electron acceptor.

\begin{tabular}{lc}
\hline Additions & $\begin{array}{c}\text { Photosynthetic } \mathrm{O}_{2} \text {-evolution } \\
{\left[\mu \mathrm{mol} \mathrm{O}_{2} / \mathrm{mg} \mathrm{Chl} \times \mathrm{h}\right]}\end{array}$ \\
\hline None & 70.0 \\
$50 \mu \mathrm{g} \mathrm{melanoprotein}_{200 \mathrm{MeCl}_{3}}$ & 71.5 \\
$200 \mu \mathrm{M} \mathrm{FeCl}_{3}+$ & 34.0 \\
$50 \mu \mathrm{g} \mathrm{melanoprotein}_{200 \mu \mathrm{M} \mathrm{FeSO}_{4}}$ & 70.0 \\
$200 \mu \mathrm{M} \mathrm{FeSO}_{4}+$ & 13.0 \\
$50 \mu \mathrm{g} \mathrm{melanoprotein}_{20 \mu \mathrm{M} \mathrm{CuSO}}$ & 71.5 \\
$20 \mu \mathrm{M} \mathrm{CuSO}$ & \\
$50 \mu \mathrm{g} \mathrm{melanoprotein}_{4}$ & 2.0 \\
\hline
\end{tabular}

The reaction mixture contained $50 \mathrm{~mm}$ Na-HEPES, pH 6.5, $1 \mathrm{~mm}$ phenyl- $p$-benzoquinone, thylakoid membranes corresponding to $25 \mu \mathrm{g}$ chlorophyll and $\mathrm{FeSO}_{4}$, $\mathrm{FeCl}_{3}$ and $\mathrm{CuSO}_{4}$ as indicated. The thylakoids membranes were preincubated in the presence of metal salts and/or melanoprotein in the Clark electrode for $5 \mathrm{~min}$.

tein and this mixture is added to the reaction mixture, no inhibition of the $\mathrm{O}_{2}$ evolution occurs. This suggests that $\mathrm{Fe}(\mathrm{II})$ is tightly bound to the melanoprotein.

\section{Production of an antiserum against the} melanoprotein and investigation of the localization of the protein in the infected M. domestica cv. Elstar

An antiserum against the purified melanoprotein was raised in a goat, and the antiserum was used to study the localization in $M$. domestica infected by $V$. inaequalis. In Western blot analyses of total leave extracts, intercellular washing fluid, and extracts of the infiltrated leaves from which the intercellular washing fluid was obtained, were investigated. The results show that the melanoprotein was only detectable in the leaves of the infected plant, and that it was mainly located in the intercellular washing fluid of the apoplast (see Fig. 3).

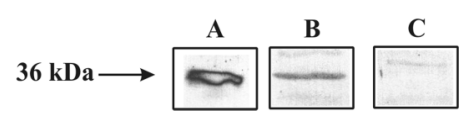

Fig. 3. Immunological detection of the melanoprotein in the apoplastic fluid of apple leaves. A: The purified melanoprotein from $V$. inaequalis, B: The apoplastic fluid from $V$. inaequalis infected leaves from $M$. domestica $\mathrm{cv}$. Elstar; C: The apoplastic fluid from non-infected leaves. Samples were subjected to SDS-PAGE and subsequently immunostained by the anti-melanoprotein antiserum (dilution 1:500) followed by an alkaline phosphatasecoupled anti goat IgG. Each lane was loaded with $25 \mu \mathrm{g}$ protein.

\section{Conclusion}

Previous results have indicated that the melanoprotein produced by $V$. inaequalis facilitates the progress of the apple scab disease (Hignett et al., 1984). As our results show, the fungus $V$. inaequalis clone No. 36 isolated from $M$. domestica cv. Gloster also excretes a melanoprotein in relatively high amount. This might be of significant importance for optimisation of the infection of $M$. domestica by this fungus, since $V$. inaequalis does not form haustoria. This protein having a molecular mass of the native protein of $36 \mathrm{kDa}$ was mainly detected in the apoplast of the infected $M$. domestica. Besides its function in increasing the number of deletions in the host plant, the protein might have an important function in recruiting iron for the pathogen. This should especially been seen under the aspect that iron is frequently a limiting factor due to its reduced bioavailability. Therefore, this melanoprotein might help the fungus in the competition of the host plant with the pathogen for this cofactor of many essential iron proteins/enzymes. It is interesting that this protein also binds copper 
in addition to iron. Copper is a cofactor e.g. $\mathrm{Cu} /$ $\mathrm{Zn}$ superoxide dismutase. Besides its function in iron and/or copper homeostasis and transport the melanoprotein might also have a function in the detoxification of iron and copper leading to a reduction in oxidative stress in the apoplast. This would also protect the fungus, since the fungus is in part located in the apoplast. Although we are able to sequence almost $40 \%$ of the protein no significant sequence homologies to other proteins in databases were found. This makes a complete sequencing of the protein rather desirable to allow a more extended sequence analysis, especially with other siderophore type proteins or other iron (and copper) binding proteins to eventually elucidate the exact function which this melanoprotein has in the process of the infection of $M$. domestica plants by the fungus $V$. inaequalis.

Anderson J. V., Haskell D. W., and Guy C. L. (1994), Differential influence of ATP on native spinach 70kilodalton heat-shock cognates. Plant Physiol. 104, $1371-1380$.

Berthold D. A., Babock G. T., and Yocum C. Y. (1981), A highly resolved, oxygen-evolving photosystem II preparation from thylakoid membranes. FEBS Lett. 134, $231-234$.

Blum H., Beier H., and Gross H. J. (1987), Improved silver staining of plant proteins RNA and DNA in polyacrylamide gels. Electrophoresis 8, 93-99.

El Bassam S., Benhamou N., and Carisse O. (2002), The role of melanin in the antagonistic interaction between the apple scab pathogen Venturia inaequalis and Microsphaeropsis ochracea. Can. J. Microbiol. 48, 349-358.

Gau A. E., Koutb M., Piotrowski M., and Kloppstech K. (2004), Accumulation of pathogenesis-related proteins in the apoplast of a susceptible cultivar of apple (Malus domestica cv. Elstar) after infection by Venturia inaequalis and constitutive expression of PR genes in the resistant cultivar Remo. Eur. J. Plant Pathol. 110, $703-711$.

Hignett R. C. (1973), The absorption of silver-labelled fungal pigment by bacterial and apple plant ribosomes. J. Gen. Microbiol. 79, 95-101.

Hignett R. C. and Kirkham D. S. (1967), The role of extracellular melanoprotein of Venturia inaequalis in host susceptibility. J. Gen. Microbiol. 48, 269-275.

\section{Acknowledgements}

We thank Dr. F. Klobasa [Institute of Livestock Breeding and Animal Behaviour, Mariensee (FAL), Germany] for the production of polyclonal antibodies against the melanoprotein and Mrs. K. Schulze (Institute of Vegetable and Fruit Science Division, Hannover, Germany) for providing different $V$. inaequalis clones. We are very thankful to Prof. Dr. W. Horst (Institute of Plant Nutrition, Hannover, Germany) and especially to Mrs. T. Edler for her excellent technical assistance concerning the iron determinations. P. S. expresses his gratitude to DAAD for a short term fellowship. The financial support and many helpful discussions by Prof. Dr. K. Kloppstech are gratefully acknowledged.
Hignett R. C., Roberts A. L., and Carder J. H. (1984), Melanoprotein and virulence determination of Venturia inaequalis. Physiol. Plant Pathol. 24, 321-330.

Jensen O. N., Wilm M., Schevchenko A., and Mann M. (1998), Sample preparation methods for mass spectrometric peptide mapping directly from 2-D gels. In: 2-D Proteome Analysis Protocols, Methods in Molecular Biology, vol. 112 (Link A. J., ed.). Humana Press Inc., Totowa, N. J., pp. 513-530.

MacHardy W. E. (1996), Apple Scab: Biology, Epidemiology, and Management. APS Press, St. Paul, Minnesota, USA.

Parker D. M., Hilber U. W., Bodmer M., Smith F. D., Yao C., and Koller W. (1995), Production and transformation of conidia of Venturia inaequalis. Phytopathology 85, 87-91.

Schägger H. and von Jagow G. (1987), Tricine-sodium dodecyl sulfate-polyacrylamide gel electrophoresis for the separation of proteins in the range from 1 to 100 kDa. Anal. Biochem. 166, 368-379.

Specht S., Pistorius E. K., and Schmid G. H. (1987), Comparison of photosystem II complexes isolated from tobacco and two chlorophyll deficient tobacco mutants. Photosynth. Res. 13, 47-56.

Towbin H., Staehelin T., and Gordon J. (1979), Electrophoretic transfer of proteins from polyacrylamide gels to nitrocellulose sheets: procedure and some applications. Proc. Natl. Acad. Sci. USA 76, 4350-4354. 